\title{
Sickle cell disease: knowledge and clinical practice of dental surgeons at Family Health Units
}

\author{
Doença falciforme: conhecimento e atuação de cirurgiões-dentistas \\ de Unidades de Saúde da Família
}

\author{
Ana Cláudia ALVES e LUNA ${ }^{1}$ iD 0000-0003-2344-1792 \\ Caroline Maria Igrejas LOPES ${ }^{1}$ iD 0000-0002-1862-0107 \\ Jakeline Cabral da Silva OLIVEIRA ${ }^{1}$ iD 0000-0002-2623-779X \\ Valdenice Aparecida de MENEZES ${ }^{1}$ iD 0000-0003-4183-3239
}

\section{ABSTRACT}

Objective: This study analyzes dental surgeons' knowledge and clinical practice regarding sickle cell disease (SCD) at Family Health Units in Recife, northeastern Brazil. Methods: This cross-sectional study was conducted in a representative sample of dentists using a standardized questionnaire. Data were analyzed by descriptive statistics. Results: Out of 132 eligible dental surgeons, 124 (93.9\%) were interviewed. Most of them were women (81.5\%), aged between 28 and 39 years (53.2\%), with more than 15 years of experience (52.4\%). A percentage of $89.5 \%$ knew the definition and oral manifestations (53.2\%) of the disease, but only $17.7 \%$ knew the dental care protocol. It was verified that $13.6 \%$ of the dentists who knew how to conduct the treatment had acquired this knowledge during their undergraduate studies. Conclusion: Regarding clinical practice, 71.8\% said they would treat patients with SCD; however, $67.7 \%$ had never done that. Most dentists felt confident of performing dental procedures (82\%) and their major difficulty was their lack of knowledge about the disease $(57.1 \%)$. The findings suggest the need for the implementation of public policies for improving the qualification of dental surgeons who work in primary healthcare, thus minimizing risks during the dental care of SCD patients.

Indexing terms: Anemia, sickle cell. Dental care. Family Health Strategy.

\section{RESUMO}

Objetivo: Este estudo analisa o conhecimento e a atuação sobre doença falciforme de cirurgiões-dentistas de Unidades de Saúde da Família no Recife/Pernambuco. Métodos: O estudo transversal foi conduzido em amostra representativa de profissionais utilizando-se questionário padronizado. Os dados foram analisados por estatística descritiva. Resultados: Dos 132 cirurgiões-dentistas elegíveis, 124 (93,9\%) foram entrevistados. A maioria era composta por mulheres (81,5\%) com idade entre 28 e 39 anos (53,2\%), com mais de 15 anos de formado (52,4\%). Um percentual de 89,5\% sabia a definição e as manifestações bucais (53,2\%) da doença, apenas $17,7 \%$ conhecia o protocolo de atendimento odontológico. Verificou-se que 13,6\% dos profissionais que conheciam o manejo do atendimento obtiveram esse conhecimento durante o curso de graduação. Quanto à atuação, 71,8\% dos profissionais atenderia paciente com doença falciforme, no entanto, $67,7 \%$ dos profissionais nunca fizeram este acolhimento. A maioria se sente seguro

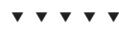

1 Universidade de Pernambuco, Faculdade de Odontologia de Pernambuco, Departamento de Odontopediatria. Av. Gal. Newton Cavalcanti, 1650, 54756-220, Tabatinga, Camaragibe, PE, Brasil. Correspondence to: AC ALVES E LUNA. E-mail: <claudialuna20@hotmail.com>.

$\boldsymbol{\nabla} \boldsymbol{\nabla} \boldsymbol{v}$

How to cite this article

Alves e Luna AC, Lopes CMI, Oliveira JCS, Menezes VA. Sickle cell disease: knowledge and clinical practice of dental surgeons at Family Health Units. RGO, Rev Gaúch Odontol. 2020;68:e20200013. http://dx.doi.org/10.1590/1981-863720200001320180027
} 
para realizar procedimentos odontológicos (82\%) e a principal dificuldade para o atendimento foi à falta de conhecimento sobre o assunto (57,1\%). Conclusão: Este resultado sugere a necessidade da implementação de politicas públicas que objetivem reforçar a capacitação dos cirurgiões-dentistas que atuam na atenção básica, a fim de minimizar os riscos durante o atendimento odontológico desses pacientes.

Termos de indexação: Assistência Odontológica; Anemia falciforme. Estratégia Saúde da Família.

\section{INTRODUCTION}

Sickle cell disease (SCD) is a group of genetic disorders characterized by a mutated form of hemoglobin - hemoglobin S (HbS), which include sickle cell anemia (HbSS) and double heterozygosity, i.e., association of $\mathrm{HbS}$ with other variants of hemoglobin, such as $\mathrm{HbD}$ and $\mathrm{HbC}$ and interactions with thalassemia ( $\mathrm{HbS} / \mathrm{a}$ thalassemia; $\mathrm{HbS} / \beta+$ thalassemia; and $\mathrm{HbS} / \beta 0$ thalassemia) [1]. SCD is one of the most common inherited hemoglobinopathies around the world. It is caused by a mutation in nucleotides, consisting of valine for glutamic acid substitution in the codon for amino acid 6 in the beta-globin subunit. This amino acid substitution leads to changes in the physical properties of the globin chain, with HbS polymerization during physiological stress, especially hypoxia, causing erythrocytes to change into a sickle shape [2].

The first signs of the disease are observed in early childhood, and the disease can eventually kill before the age of 30 years [3]. SCD plays an important role in public health, as it may increase infant and child mortality rates, mainly among children younger than 5 years, as a result of severe anemia episodes associated with splenomegaly, causing extremely severe infections $[4,5]$. Among clinical manifestations, pain crises are the most common and most important symptom of SCD. Erythrocyte sickling leads to several acute and chronic complications, including anemia, severe infections, hemolytic and vaso-occlusive crises, bouts of recurrent pain, cerebral vascular accident, acute chest syndrome, pulmonary hypertension, and chronic organ injuries [6, 7].

Regarding oral manifestations, the clinical signs most frequently described in the literature include pale mucous membrane, delayed tooth eruption, enamel and dentin demineralization, hypercementosis, pulp calcifications, changes in cells on the surface of the tongue, and bone changes, leading to upper jaw protrusion and formation of a thick trabecular pattern [8]. Moreover, some studies have reported higher prevalence of dental caries and periodontal disease $[9,10]$.
Within this context, dental surgeons play a crucial role in the prevention of oral complications by reducing the likelihood of infections and thus improving patients' quality of life [11]. In addition, dental surgeons should exercise their creativity and critical thinking concerning humane and effective practices that include promotion, prevention, recovery, and rehabilitation of oral health, using a healthcare model with a holistic view of the patients and of the community they belong to $[12,13]$.

As SCD is a public health problem, the Brazilian Ministry of Health adopted the policy for the comprehensive care of people with SCD in 2007 with the aim of promoting some change in the natural history of the disease, reduction in morbidity and mortality, and improvement of patients' quality of life [14]. Dental care of patients with SCD prompted several towns to offer qualification courses for professionals following specific protocols. The present study aimed to assess the knowledge and clinical practice of dental surgeons regarding SCD at family health units.

\section{METHODS / ORIGINAL ARTICLE}

A cross-sectional study was conducted with a representative sample of dental surgeons from family health units in Recife, Brazil, between March and October 2013. Recife, state capital of Pernambuco, in the northeast of Brazil, has an area of $218.435 \mathrm{~km} 2$ and a population estimated at 1.6 million inhabitants [15]. The city is divided into six health districts and employs 253 family health teams and 132 oral health teams, distributed across 120 family health units.

Dental surgeons answered a questionnaire with 13 closed-end questions previously validated by the "face" method, in order to assess their knowledge of and practice with SCD [16]. The definition of the disease was considered to be comprehensive when the dental surgeon answered it was a genetic disorder associated with distorted (sickleshaped) red blood cells. On the other hand, the definition was considered incomplete when the dental surgeon failed to mention either of these two characteristics: genetic disorder or distorted red blood cells. For the sake 
of analysis, both definitions were considered satisfactory. As far as the dental surgeon's work was concerned, whether the health service was provided at a family health unit, whether qualification was offered, and the major difficulties encountered were taken into account. Only those dental surgeons who agreed to participate in the study were selected, and those who did not work at a family health unit in Recife were excluded from the study.

The collected data were entered into an EXCEL spreadsheet and analyzed descriptively using absolute and percent frequencies.

The study protocol was approved by the Research Ethics Committee of Universidade de Pernambuco (UPE), process CAAE: 4771.0.097.000-10.

\section{RESULTS}

Out of 132 eligible dental surgeons, 124 (93.9\%) were interviewed and eight (6.1\%) refused to participate in the study $(n=3)$ or were not present on the day of the interview $(n=5)$. Most surgeons were female $(81.5 \%)$, aged 28 to 39 years $(53.2 \%)$, with more than 15 years of experience $(52.4 \%)$, and had attended public dental schools (92.5\%) (Table 1).

Table 1. Characteristics of dental surgeons who work at family health units, including sex, age, years of experience, health district, and type of school attended. Recife (PE), 2013.

\begin{tabular}{lcc}
\hline Variable & $\mathrm{n}$ & $\%$ \\
\hline Sex & 23 & 18.5 \\
Male & 101 & 81.5 \\
Female & & \\
Age (in years) & 66 & 53.2 \\
28 to 39 & 58 & 46.8 \\
40 to 67 & & \\
Years of experience & 59 & 47.6 \\
Up to 15 & 65 & 52.4 \\
16 or more & & \\
Health district & 9 & 7.3 \\
I & 21 & 16.9 \\
II & 23 & 18.5 \\
III & 27 & 21.8 \\
IV & 12 & 9.7 \\
V & 32 & 25.8 \\
VI & & \\
Type of school attended & 115 & 92.5 \\
Public & 9 & $\mathbf{1 0 0 . 0}$ \\
Private & $\mathbf{1 2 4}$ & \\
\hline TOTAL & & \\
\hline
\end{tabular}

Table 2 shows that most surgeons reported having knowledge of the definition (89.5\%) and oral manifestations $(53.2 \%)$ of the disease. Satisfactory information about the disease was reported by $78.4 \%$. Among the cited oral manifestations, periodontal disease (36.4\%) and tongue and oral mucosal disorders (18.2\%) were the most frequent ones. A small percentage of the interviewees (17.7\%) were aware of the dental care protocol.

Table 2. Distribution of interviewees according to their knowledge about sickle cell disease. Recife (PE), 2013.

\begin{tabular}{lcr}
\hline Variable & $\mathrm{N}$ & $\%$ \\
\hline Do you know what sickle cell disease is? & & \\
Yes & 111 & 89.5 \\
No & 13 & 10.5 \\
\hline TOTAL & $\mathbf{1 2 4}$ & $\mathbf{1 0 0 . 0}$ \\
\hline Definition of sickle cell disease & & \\
Comprehensive & 8 & 7.2 \\
Incomplete & 79 & 71.2 \\
Incorrect & 18 & 16.2 \\
Did not answer/ does not know & 6 & 5.4 \\
\hline TOTAL & $\mathbf{1 1 1}$ & $\mathbf{1 0 0 . 0}$ \\
\hline Do you know whether this disease has oral manifestations? & & \\
Yes & 66 & 53.2 \\
No & 58 & 46.8 \\
\hline TOTAL & $\mathbf{1 2 4}$ & $\mathbf{1 0 0 . 0}$ \\
\hline
\end{tabular}

If so, do you know what the oral manifestations of sickle cell disease are?

\begin{tabular}{lcc} 
Yes & 33 & 50.0 \\
No & 33 & 50.0 \\
\hline TOTAL & $\mathbf{6 6}$ & $\mathbf{1 0 0 . 0}$ \\
\hline What are the oral manifestations of sickle cell disease? & & \\
Enamel and dentin demineralization & 3 & 9.1 \\
Dental caries & 2 & 6.1 \\
Periodontal disease & 12 & 36.4 \\
Malocclusion & - & - \\
Changes in tongue and oral mucosa & 6 & 18.2 \\
Other & 9 & 27.3 \\
\hline BASE ${ }^{(1)}$ & 33 & - \\
\hline
\end{tabular}

Do you know the healthcare protocol for patients with sickle cell disease?

\begin{tabular}{lcc} 
Yes & 22 & 17.7 \\
No & 102 & 82.3 \\
\hline TOTAL & $\mathbf{1 2 4}$ & $\mathbf{1 0 0 . 0}$ \\
\hline If so, where did you learn about it? & & \\
In college & 3 & 13.6 \\
In the graduate program & 1 & 4.5 \\
In a qualification course & 12 & 54.5 \\
Other & 8 & 36.4 \\
\hline BASE $^{(1)}$ & $\mathbf{2 2}$ & - \\
\hline
\end{tabular}

(1): As the same dental surgeon could choose more than one option, only the base for calculation of percentage values, rather than the total, is considered. 
Table 3 reveals that most surgeons (67.7\%) did not attend to patients with SCD, but $71.8 \%$ said they would treat patients with this hemoglobinopathy.

Table 3. Distribution of interviewees according to the healthcare provided to patients with sickle cell disease. Recife (PE), 2013

\begin{tabular}{|c|c|c|}
\hline Variable & $\mathrm{N}$ & $\%$ \\
\hline \multicolumn{3}{|l|}{$\begin{array}{l}\text { What is your attitude towards a patient with sickle cell } \\
\text { disease? }\end{array}$} \\
\hline You treat him/her & 89 & 71.8 \\
\hline You do not treat him/her & 34 & 27.4 \\
\hline Did not answer & 1 & 0.8 \\
\hline TOTAL & 124 & 100.0 \\
\hline \multicolumn{3}{|l|}{ Have you ever treated a patient with sickle cell disease? } \\
\hline Yes & 39 & 31.5 \\
\hline No & 84 & 67.7 \\
\hline Do not know & 1 & 0.8 \\
\hline TOTAL & 124 & 100.0 \\
\hline \multicolumn{3}{|l|}{ If so, did you have any difficulty during dental care? } \\
\hline Yes & 4 & 10.3 \\
\hline No & 35 & 89.7 \\
\hline TOTAL & 39 & 100.0 \\
\hline \multicolumn{3}{|l|}{$\begin{array}{l}\text { If you treat the patient, do you have confidence in } \\
\text { performing dental procedures? }\end{array}$} \\
\hline Yes & 73 & 82.0 \\
\hline No & 14 & 15.7 \\
\hline Did not answer & 2 & 2.2 \\
\hline TOTAL & 89 & 100.0 \\
\hline \multicolumn{3}{|l|}{$\begin{array}{l}\text { Justification for those who answered "yes" to the previous } \\
\text { questions }\end{array}$} \\
\hline The patient is followed up at the health unit & 4 & 5.5 \\
\hline You request a medical assessment & 54 & 74.0 \\
\hline You perform only noninvasive (preventive) procedures & 9 & 12.3 \\
\hline Did not answer & 2 & 2.7 \\
\hline You look further into the topic & 4 & 5.5 \\
\hline TOTAL & 73 & 100.0 \\
\hline \multicolumn{3}{|l|}{ Justification for those who answered "no" to the question } \\
\hline You lack confidence in performing the procedures & 1 & 7.1 \\
\hline You lack knowledge about the disease & 8 & 57.1 \\
\hline Most patients do no have proper follow-up & 2 & 14.3 \\
\hline The health unit lacks support & 2 & 14.3 \\
\hline Did not answer & 1 & 7.1 \\
\hline TOTAL & 14 & 100.0 \\
\hline
\end{tabular}

(1): As the same dental surgeon could choose more than one option, only the base for calculation of percentage values, rather than the total, is considered.

\section{DISCUSSION}

The present study allowed checking the knowledge of dental surgeons from the family health strategy system in Recife regarding SCD. In general, most surgeons knew how to define SCD $(89.5 \%)$, but despite the fact that the answer was considered satisfactory $(78.4 \%)$, only $7.2 \%$ gave a comprehensive answer. This highlights the importance of specific guidance during qualification courses.

As for the oral manifestations of SCD mentioned in this study, periodontal disease and tongue and oral mucosal disorders were the most frequent ones; however, $27.3 \%$ of the interviewees mentioned oral manifestations that were unrelated to SCD and no interviewee mentioned malocclusion as a consequence of SCD. It should be noted that malocclusion is highly prevalent among children and adolescents with SCD, with severe cases resulting from compensatory expansion of the bone marrow [17].

Regarding the dental care protocol for patients with SCD, results indicate the "invisibility" of the disease in the health system over the years, since patients were referred to hematologic centers after diagnosis and were maintained there for the rest of their lives, followed up by hematologists and excluded from health prevention and promotion programs [18]. According to the National Policy for Comprehensive Healthcare of Patients with Sickle Cell Disease and Other Hemoglobinopathies, it is important to have a policy for qualification of all primary healthcare providers and for permanent health education, as SCD is the most prevalent hematologic disease in Brazil, with a prevalence rate in the state of Pernambuco of 1 in 1,400 live births $[4,19,20]$.

Most dental surgeons showed confidence in performing dental procedures on SCD patients. When asked about the reason for their confidence, most surgeons said they request a medical assessment before dental care, followed by professionals who only performed preventive procedures. Therefore, qualification of health professionals is essential in order to provide them with knowledge of the disease, contributing to better clinical decision making, promoting health, providing self-care, and debunking the myth about this disease [21].

Among those dental surgeons who reported lack of confidence in treating patients with SCD, most mentioned their lack of knowledge about the disease, as described by Coutinho [22]. Other reasons included absence of follow-up of patients and lack of support at 
the health unit. Note that the resources necessary for comprehensive healthcare provision at the unit were not mentioned. In other studies, the physical structure of the units, the working conditions, and the availability of materials, equipment and/or instruments were addressed $[23,24]$.

Healthcare is not provided to SCD patients in primary settings because professionals feel insecure and unprepared to give them quality care [25]. In the present study, $27.4 \%$ of health professionals did not attend to patients with SCD, but they referred the patients to a reference hematologic center. This shows the need for reorganization and restructuring of the healthcare network to meet the needs of SCD patients, rendering the family health strategy the mainstay of health services offered at all levels [26]. This reorganization should include the registration of SCD patients, which is important from an epidemiological standpoint and for healthcare planning. Moreover, SCD patients cannot be easily tracked at family health units.

Dental surgeons play an important role in the prevention of oral complications of SCD and oral health status can have a great impact on general health and on the quality of life of SCD patients [14, 27]. The healthcare provided to these patients at family health units forges a link between users and the health team, promoting a comprehensive approach, reducing morbidity and mortality, and increasing life expectancy of SCD patients [18].

The Brazilian Ministry of Health published some manuals on dental care of SCD patients; the latest one was published in 2014, with the main objective of sharing knowledge about the disease and dispelling any doubts about the treatment protocol among dentists [20]. It should be highlighted that dental treatment should occur during the chronic stage of the disease, but if therapy is needed during the acute phase, it should be targeted at palliative care and should only be implemented after careful history taking and clinical examination. The history and complications of the disease must be considered, as well as the physical and emotional statuses and tolerance of surgical procedures, in order to eliminate or reduce the risk of associated systemic infections, using prophylactic and preventive regimen and stress of these patients, since this could lead to a sickle cell disease crisis $[4,28]$.

Among dental procedures, oral surgeries are invasive and riskier to the patient, and they should therefore be planned so that the intervention is safe. In such cases, the dental surgeon has to request a complete blood count [29]. As far as local anesthesia is concerned, the use of vasoconstrictors is controversial [28]. If the treatment plan is short and well-planned, routine dental procedures can be performed using an anesthetic without a vasoconstrictor [4].

Another extremely relevant factor for dental care is the susceptibility to infections triggered by SCD. Because invasive procedures may cause bleeding and bacteremia, antibiotic prophylaxis should be used prior to the treatment, except for children aged 5 years or younger treated regularly with oral or parenteral penicillin [4]. In children older than 5 years, there is no particular antibiotic prophylaxis for SCD and, thus, treatment should follow the routine protocol used for the general population [30].

In order for an SCD patient to be followed up properly, it is essential to have a multiprofessional team in primary healthcare. The organization of dental care networks and qualification of health professionals are key to the success of this process. The structure of this decentralized healthcare system for SCD patients is supported by the Brazilian Ministry of Health, ordinance no. 1.391, of August 16, 2005, and also by the World Health Organization, which recommends the follow-up of SCD patients in the primary healthcare setting $[5,19]$.

\section{CONCLUSION}

Most dental surgeons know how to define SCD satisfactorily, but they do not know the dental care protocol and they do not attend to SCD patients. Therefore, specific public policies are necessary for permanent qualification of dental surgeons who work in the primary healthcare setting, in order to minimize the risks during clinical treatment, in addition to contributing to maintaining the quality of life of these patients.

\section{Collaborators}

Ana Cláudia Alves and Luna conducted the research and were involved in the planning, analysis, and draft of the manuscript. Caroline Maria Igrejas Lopes participated in the planning, analysis, and draft of the manuscript. Jakeline Cabral da Silva Oliveira performed the analyses and interpreted the data. Valdenice Aparecida de Menezes conceived the original idea, oversaw the research project, and was in charge of the critical review and approval of the final version of the manuscript. 


\section{REFERENCES}

1. Arduini GA, Rodrigues LP, Trovó de Marqui AB. Mortality by sickle cell disease in Brazil. Rev Bras Hematol Hemoter. 2017;39(1):52-56. https://doi.org/10.1016/j.bjhh.2016.09.008

2. Raghunathan VM, Whitesell PL, Lim SH. Sleep-disordered breathing in patients with sickle cell disease. Ann Hematol. 2018;97(5):755-762. https://doi.org/10.1007/s00277-017-3199-z

3. Loureiro MM, Rozenfeld S. Epidemiology of sickle cell disease hospital admissions in Brazil. Rev Saude Publica. 2005; 39(6):1-6. https://doi.org/10.1590/S0034-89102005000600012

4. Brasil. Ministério da Saúde. Secretaria de Atenção à Saúde. Departamento de Atenção Especializada. Manual de saúde bucal na doença falciforme. Brasília: Ministério da Saúde; 2007 [citado 2018 jul 10]. Disponível em: https://www.nupad. medicina.ufmg.br/wp-content/uploads/2016/12/manual_sb_ doenca_falciforme_2007.pdf.

5. World Health Organization. Sickle-cell anaemia. Fifty-Ninth World Health Assembly; 2006.

6. Steinberg $\mathrm{MH}$. Genetic etiologies for phenotypic diversity in sickle cell anemia. Sci World J. 2009; 9:46-67. https://doi. org/10.1100/tsw.2009.10

7. Therrell BL Jr, Lloyd-Puryear MA, Eckman JR, Mann MY. Newborn screening for sickle cell diseases in the United States: A review of data spanning 2 decades. Semin Perinatol. 2015;39(3):238-51. https://doi.org/10.1053/j.semperi.2015. 03.008

8. Pithon MM. Orthodontic treatment in a patient with sickle cell anemia. Am J Orthod Dentofacial Orthop. 2011;140(5):713-9. https://doi.org/10.1016/j.ajodo.2010.02.039

9. Luna ACA, Rodrigues MJ, Menezes VA, Marques KM, Santos FA. Caries prevalence and socioeconomic factors in children with sickle cell anemia. Braz Oral Res. 2012;26(1):43-49. https://doi.org/10.1590/\$1806-83242012000100008

10. Singh J, Singh N, Kumar A, Kedia NB, Agarwal A. Dental and periodontal health status of Beta thalassemia major and sickle cell anemic patients: a comparative study. J Int Oral Health. 2013;5:53-58.

11. Okafor LA, Nonnoo DC, Ojehanon PI, Aikhionbare O. Oral and dental complications of sickle cell disease in Nigerians. Angiology. 1986;37(9):672-5. https://doi.org/10.1177/0003 31978603700909

12. Brasil. Ministério da Saúde. O CNS e a Construção do SUS: referências estratégicas para melhoria do modelo de atenção a saúde. Brasília: Ministério da Saúde; 2003 [citado 2018 jul 10]. Disponível em: http://conselho.saude.gov.br/biblioteca/ livros/cnseaconsrucaodosus.pdf

13. Noronha MGRCS, Cardoso PS, Moraes TNP, Centa ML. Resiliência: nova perspectiva na promoção da saúde da família? Cienc Saude Colet. 2009;14(2):497-506. https://doi. org/10.1590/S1413-81232009000200018

14. Brasil. Ministério da Saúde. Secretaria de Atenção à Saúde. Departamento de Atenção Especializada. Manual de Educa- ção em Saúde. Autocuidado na Doença Falciforme. Brasília: Ministério da Saúde; 2008 [citado 2018 jul 10]. Disponível em: http://bvsms.saude.gov.br/bvs/publicacoes/manual_ educacao_saude_volume1.pdf.

15. Instituto Brasileiro de Geografia e Estatística (IBGE). Censo 2017 [citado 2018 jul 25]. Disponível em: https://cidades. ibge.gov.br/brasil/pe/recife/panorama.

16. Frankfort-Nachimias C, Nachimias D. Research methods in the social sciences. 4. ed. London: Edward Arnold; 1992.

17. Alves e Luna AC, Godoy F, de Menezes VA. Malocclusion and treatment need in children and adolescents with sickle cell disease. Angle Orthod. 2014;84(3):467-72. https://doi. org/10.2319/070913-503.1

18. Brasil. Ministério da Saúde. Secretaria de Atenção à Saúde. Departamento de Atenção Especializada. Manual de educação em saúde. Linha de Cuidado em Doença Falciforme. Brasília: Ministério da Saúde; 2009 [citado 2018 jul 10]. Disponível em: http://bvsms.saude.gov.br/bvs/publicacoes/manual_educacao_ saude_v2.pdf.

19. Brasil. Ministério da Saúde. Portaria $n^{\circ} 1.391$, de 16 de Agosto de 2005. Institui no âmbito do Sistema Único de Saúde, as diretrizes para a Política Nacional de Atenção Integral às Pessoas com Doença Falciforme e outras Hemoglobinopatias. Brasília (DF): Diário Oficial da União; 2005 [citado 2018 jul 12]. Disponível em: http://bvsms.saude.gov.br/bvs/saudelegis/ gm/2005/prt1391_16_08_2005.html

20. Brasil. Ministério da Saúde. Secretaria de Atenção à Saúde. Departamento de Atenção Hospitalar e de Urgência. Doença falciforme: saúde bucal: prevenção e cuidado. Brasília: Ministério da Saúde; 2014 [citado 2018 jul 12]. Disponível em: http://bvsms.saude.gov.br/bvs/publicacoes/doenca_falciforme_ saude_bucal_prevencao.pdf

21. Serafim ESS, Soares RM, Oliveira TMX, Soares MJNL. Capacitação de profissionais de saúde para o manejo da dor em adolescentes portadores de doença falciforme na atenção primária. Adolesc Saude. 2011;8(4):55-58.

22. Coutinho TCL. Avaliação do atendimento clínico às crianças portadoras de anemia falciforme pelos odontopediatras do município do Rio de Janeiro-RJ. Rev Flum Odontol. 2010;(33):20-26.

23. Marqui $A B T$, Jahn AC, Resta DG, Colomé ICS, Rosa N, Zanon T. Caracterização das equipes da Saúde da Família e de seu processo de trabalho. Rev Esc Enferm USP. 2010;44(4):95661. https://doi.org/10.1590/S0080-62342010000400014

24. Sousa FGM, Erdmann AL, Mochel EG. Condições limitadoras para a integralidade do cuidado à criança na atenção básica de saúde. Texto \& contexto enferm. 2011;20: 263-71. https:// doi.org/10.1590/S0104-07072011000500033

25. Kikuchi BA. Assistência de enfermagem na doença falciforme nos serviços de atenção básica. Rev Bras Hematol Hemoter. 2007;29(3):331-38. https://doi.org/10.1590/\$1516-8484200 7000300027

26. Brasil. Ministério da Saúde. Secretaria de Atenção à Saúde, Departamento de Atenção Especializada e Temática. Doença 
falciforme: Diretrizes Básicas Da Linha de Cuidado. Brasília: Ministério da Saúde; 2015 [citado 2018 jul 12]. Disponível em: http://bvsms.saude.gov.br/bvs/publicacoes/doenca_falciforme_ diretrizes_basicas_linha_cuidado.pdf.

27. Fonseca M, Queis HS, Casamassimo PS. Sickle cell anemia: a review for the pediatric dentist. Pediatr Dent. 2007;29(2):159-69.

28. Hosni JS, Fonseca MS, Silva LCP, Cruz RA. Protocolo de atendimento odontológico para paciente com anemia falciforme. Arq Bras Odontol. 2008;4(2):104-112.
29. Franco BM, Gonçalves JCH, Santos CRR. Manifestações bucais da anemia falciforme e suas implicações no atendimento odontológico. Arq Odontol. 2007;43(3): 92-96.

30. Friedrisch JR. Anesthesia and surgery in sickle cell disease. Rev Bras Hematol Hemoter. 2007;29:304-8. https://doi.org/10. 1590/S1516-84842007000300022.

Received on: 1/11/2018

Final version resubmitted on: 3/4/2019

Approved on: 17/5/2019 